\title{
THE IMPLEMENTATION OF CASHLESS ZONE AS A STRATEGY TO PREVENT CORRUPTION IN INDONESIA
}

\author{
Hj. Fatria Khairo., STP., SH., MH. \\ Sekolah Tinggi Ilmu Hukum - Sumpah Pemuda
}

\section{ARTICLE INFORMATION}

Article history:

Received May 04, 2016

Revised Dec 23, 2016

Accepted May 19, 2017

\section{JEL Classifications}

D73; H59; H79

\section{Key Words:}

Corruption Prevention;

Budget Planning;

Honesty;

Building leadership role-model

DOI:

10.21532/apfj.001.17.02.01.009

\begin{abstract}
There are many ways to solve the problem of corruption in Indonesia. Therefore, this paper aims to analyze the corruption prevention strategy by implementing Cashless Zone culture as one of the alternatives to prevent corruption in Indonesia, in addition to enforcing control functions over budget planning and its execution, establishing honesty, and building leadership role-model.
\end{abstract}

\section{A. INTRODUCTION}

The causal factors of the rampant and the prevalence of corruption in all aspects of life in Indonesia are very diverse and intertwined from one to another. They have become a vicious circle that cannot be separated from each other and difficult to find out which one that becomes the dominant trigger of corruption. Some of the causes have made the corruption become sustainable and entrenched. Procurement of goods and services is the most vulnerable area to corruption, as in the case occurring in South Sumatra, (Sumsel Post, Issued September 29, 2015, p. 3). Therefore, corruption in Indonesia has been classified as an extraordinary crime. ${ }^{1}$

Cases of corruption are difficult to disclose because the perpetrators use sophisticated equipment and the actions are usually committed by more than one person in a shrouded and organized manner, and therefore this crime is often referred to as white collar crime. ${ }^{2}$ Some corruption cases revealed during a press conference of the

1 Ermansjah Djaja, Tipologi Tindak Pidana Korupsi di Indonesia, CV. Mandar Maju, Bandung, 2010, p. 13.

2 Evi Hartanti, Tindak Pidana Korupsi, Sinar Grafika, Jakarta, 2005, p. 2. 
students of STIH Sumpah Pemuda at Judicial Commission Liaison Office of South Sumatra, on September 28, 2015, were the case of bribery of Accountability Report (LKPJ) 2014 and the approval of budget funds in Banyuasin, South Sumatra in 2015 involving the legislators of Banyuasin, the Regent and his wife.

In addition, the extent of the circulation of money in the various sectors of government in Indonesia may cause corrupt behavior among government officials.

Corruption has always originated and evolved in the public sector with tangible evidence that with the power the public officials can press or squeeze justice seekers or those who require the services of the government. The development of corruption has been the result of disorder and unsupervised governance system because the legal basis used also contains a lot of weaknesses in the implementation.

The enactment of Law on Corruption is intended to prevent and combat corruption. Criminal politics is a corruption prevention strategy that is attached to the Law on Corruption. Criminal political dimension cannot run well because the law enforcement system in Indonesia is not egalitarian. The law enforcement system applied can place corruptor on the high level above the law. The law enforcement system, which is not conducive to a democratic climate, is even worsened by the presence of institution that gives pardon to corrupt conglomerate by the consideration of interest only, and not by legal considerations.
At present although non-cash payment has been widely implemented in terms of transaction, the conventional in cash payment is still very common, thus resulting in many loopholes that allow corruption to occur. Therefore, it is necessary to implement the culture of non-cash payment or commonly known as the national Movement of Non Cash (Cashless zone) such as the implementation of e-money in order to reduce corrupt behavior of the public officials. The non-cash card has been quite widely applied in our country, but not thoroughly applied, so the implementation of cashless zone still needs to be expanded more and more.

Therefore, the authors took the initiative to conduct research on

"The Implementation of Cashless Zone Culture as a Strategy to Prevent Corruption in Indonesia"

\section{B. BACKGROUND OF THE PROBLEMS}

Based on the description above, the research questions can be formulated as follows:

1. What are strategies to prevent corruption in Indonesia?

2. How are the implementations of cashless zone culture as a strategy to prevent corruption in Indonesia?

\section{SCOPE}

Based on the background of the problems above, the authors rely on the research title of the Strategy to Prevent Corruption in Indonesia through the Implementation of Cashless Zone Culture which will be presented in chapter of 
discussion so as not to deviate from or out of the substance to be discussed.

\section{RESEARCH METHODOLOGY}

\section{Type of Research}

Normative method is applied in this research with the aim to examine the legal certainty based on the study of literature and existing positive law. The approach used in this research is doctrinal legal research.

\section{Legal Materials Used}

The legal materials used in the preparation of this paper are tertiary legal materials, such as library books, newspapers, and data from internet.

\section{Data Collection and Analysis}

The preparation of this paper is done by means of literature review through library research to obtain data from books and literature relating to the discussion of this paper. Data processing technique is conducted by recording and analyzing the data obtained using qualitative descriptive method to be constructed into a conclusion

\section{E. DISCUSSION}

1. Strategy to Prevent Corruption in Indonesia $^{3}$

a. The Willingness of the Leaders to Implement the Principles of State Financial Management

Completeness or incompleteness of legislation is not a reason to determine whether the financial management of the country is good

Surachmin dan Suhandi Cahaya, Strategi dan Teknik Korupsi, Sinar Grafika, Jakarta, 2011, p. 110-135. or bad. As long as there is a good will from the leaders to fix the financial management of an institution, even though the legislation is still incomplete and inadequate, the improvement will be achieved, because good will is the basic capital that is based on the principles that are universally accepted by people in social life. Similarly, the principles of state financial management are not entirely stipulated in the legislation, but some are created and practiced in public financial management and accepted as well as used as benchmarks / criteria in public / state financial management.

\section{b. The Enforcement of the Control Function for Budget Planning and the Execution}

Corruption is now occurring not only in the budget execution, but also in the work planning and budgeting. Therefore, it is necessary to reenforce the control function by reviewing the rules of control, principles of planning and rules of implementation.

\section{b.1. Rules of Control}

The controls of the planning / implementation of development are basically a series of activities to follow the progress of the implementation of the development and to be followed up with activities so as to be in accordance with the established plan. In this sense, the controls include the directing and coordinating the activities in the implementation of the projects so that the waste and fraud can be prevented. Thus the control activities must be objective and can reveal the facts about the plan and the execution of a job. 


\section{b.2. Principles of Planning}

Good planning should meet the dimensions of the value of the principles of governance and financial management. Good planning should give attention to the principles of good governance which accommodates the dynamic of development and social politic interaction of the community, be supported by appropriate development paradigm, and has a clear concept and accurate, comprehensive, and integrated analysis. This is necessary to achieve common perception, synergy and alignment in the field of economic and others (politic, legal, religion, education, social, culture, natural resources, environment, as well as defense and security), in addition to the growth alignment among various sectors of the economy; overall government and private sector investment; and alignment of the role of state enterprises and private companies, as well as the alignment of the role of central and local governments toward the efforts to prevent corruption.

\section{b.3. Rules of Implementation}

Implementation is a series of activities undertaken after a decision and is intended to achieve the goals, objectives or specific roles. For the objectives can be achieved efficiently and effectively, the governance and development, particularly in the implementation of state budget / regional budget, should pay attention to efficiency, effectiveness, legally compliant, transparence, decentralized, and domestic products priority, inclusion of small and medium enterprises, as well as the price and budget that are accountable to the public.

\section{b.4. The involvement of Community and NGOs through Budget Planning Legislation}

During the discussion NGOs told the House of Representative on the importance of the draft of State Budget Planning Act in preventing corruption, especially at the stage of budget planning that should be structural and systematic in managing public finances.

One of the most effective ways to prevent the misuse of the state financial management is by involving the public, especially the NGOs starting from the budget planning to the budget implementation that have some positive aspects in preventing corruption and realizing the budget in favor of the interests of the people.

\section{c. Additional Ways \\ c.1. Building Honesty version of Gunawan Fauzi}

Gamawan Fauzi is a former regent who has successfully changed the face of Solok district from the backward regions and nuanced by corruption to become an ideal district that is free of corruption, collusion and nepotism. The success led Gumawan Fauzi to become the Governor of West Sumatra province during 2005-2010 through direct election by the people. One of his programs is to eradicate corruption and eliminate image of "wet and dry" position through the tips below. (Ekpose, September, 2005. Kompas, November 2004).

The success in cutting the red tape and reducing the dirty practices in the local government project affairs has not made Gumawan satisfied. For him, the progress made by government officials of Solok District 
is still limited to the adherence to rules. It has not become an ingrained habit. Therefore, after attending an anti-corruption congress in South Korea, in 2003, he made a new breakthrough, called integrity fact. Working together with Transparency International (TI), the pact aims to build the inherent dignity and honesty of the apparatus in running the government. The pact was signed by all echelon II and III together with the regent, vice regent and district secretary, with a promise not to accept and give something illegal, as well as to meet the call of conscience not to commit corruption, collusion and nepotism.

\section{c. 2 Leadership Role-Model}

Sahid, SH provides an alternative example in eradicating corruption, namely the Leadership role-model formulated as follows.

Good leadership is quite expected since our society still has a very strong paternalistic pattern. Leadership role-modeling, both at work and in everyday life, will give a good image for him alone and his surroundings that will be followed by the staff and surrounding communities. Based on the experience in corruption cases, the members of the community are often involved. With regard to the good behavior, it is necessary to determine a code of conduct to all employees in detail, what actions that should and should not be done, accompanied by the imposition of sanctions against the violators.

In addition, it will be better if the government establishes a pilot project in the form of an institutional model, a relatively small office, which applies painstaking efforts to control themselves from acts of corruption and misconduct and obeyed by all levels of employees, as a model of island of integrity. When the model is successful, it will surely be followed by other offices to a larger area. It is expected to be the forerunner of "national anticorruption movement" which is significant to the success of the efforts to eradicate corruption in Indonesia.

2. The Implementation of Cashless Zone Culture as a Strategy to Prevent Corruption in Indonesia.

Tindakan pemberantasan korupsi oleh negara seharusnya seimbang antara upaya preventif untuk mencegah korupsi dan penindakan hukum pelaku korupsi. Namun demikian, harapan tinggi masyarakat Indonesia kepada Pemerintah untuk memberantas semua tindakan korupsi, belum terwujud. Aparat hukum negara belum mampu mencegah tindakan korupsi secara efektif.

Measures to eradicate corruption by the state should be balanced between preventive measures to prevent corruption and legal action against the perpetrators of corruption. However, the high expectations of the people of Indonesia to the Government to combat all acts of corruption have not been realized. State law enforcers have not been able to prevent corruption effectively.

In the Presidential Decree No.17 / 2011, the Government planned 105 actions to eradicate corruption starting from the transparency of public services, the establishment of whistleblower system, to the anti-corruption education 
in all ministries / state agencies. With the strategic plans, various types of corruption should have been lost, but in fact, corruption still continues. (Anandita Budi Suryana, an employee of Directorate General of Taxation).

Corruption eradication will always fail if an early warning system for the prevention of corruption is not established. The problem of corruption is not only in the bureaucratic system, but due to less strict control systems of payment transaction. So far the perpetrators of corruption can freely spend money, as the proceeds of corruption, to buy various assets and securities because it is not systematically monitored by the Government.

Then what are the best ways to prevent corruption in Indonesia? The government needs to make an affirmation of the limit of cash and non-cash payment. Non-cash payment system is like Cashless Zone, in which the payment transactions do not involve large amounts of money in cash but through banking institutions. In the United States, large amount of cash payment is taboo because those who make jumbo payment can be considered as part of the mafia. In Indonesia, there has been no culture of shame for someone who makes large transactions in cash, but even he is considered great when he makes payment transaction in cash.

Then, how? In the explanation of point 5 of the Law No.17 / 2003 on State Finance, it is explained that the President, as the public finance management authority, delegates the authority to regulate and maintain the smooth operation of payment systems to the Central
Bank. This is confirmed in Article 19 of Law No.23 / 1999 in conjunction with the Law No.6 / 2009 on Bank Indonesia (BI), that BI is authorized to enact and issue the money including its type, price, characteristics, materials used, and the date of entry into force as means of legitimate payment.

According to Chandra Hamzah, the payment system should be protected by law. In general, the rules of cash payment limitation must be discussed with the legislature to produce legislation such as the Law No.3 / 2011 on Transfer of Funds. The problem, INTRAC (hereinafter referred to as PPATK) also indicates 2,000 suspicious transactions involving the members of legislature. (Tempo, edition February 21, 2012). If this is true, the discussion of law on non-cash payment will require lengthy discussion with the legislature.

Will the cash restriction deprive the economy? In general, there are five levels of payment transactions: transactions from government to government, from government to business, business to business, business to person or person to person. BI does not need to set the five types of the above transactions. BI just needs to manage the transaction from business to business, business to person or person to person through non-cash payment mechanism.

The function of Cashless Zone setting is not only useful for the prevention of corruption, but also the recording of transactions in the banking system which will allow the State to collect taxes from the trader. During this time, the State gets difficulty to trace those who 
make multibillion rupiah transactions related to the purchase of property, luxurious jewelry, securities and vehicles. By recording cashless zone in an orderly manner, the State will easily tracks the validity of the transaction.

\section{F. CLOSING}

Based on the description above, it can be concluded as follows:

\section{A. Conclusion}

\section{Corruption Eradication Strategy in}

\section{Indonesia $^{4}$}

The willingness of the leaders to implement the principles of state financial management includes:

- The enforcement of control over the budget planning and the execution (rules of control, principles of good planning, rules of execution).

- The involvement of community and NGOs through the Budget Planning Act.

- Additional ways.

- Building honesty version Gamawan Fauzi.

- Leadership Role-Modeling.

2. The Implementation of Cashless Zone culture as a Strategy to Prevent Corruption in Indonesia.

The implementation cashless zone as a strategy to prevent corruption in Indonesia includes a non-cash payment system as the planning of preventive measures to reduce the potential for corruption occurring in this country

4 Surachmin dan Suhandi Cahaya, Strategi dan Teknik Korupsi, Sinar Grafika, Jakarta, 2011, p. 110-135.

\section{B. Suggestions}

1. The government, as the leader, should be able to implement the principles of state financial management in good faith and does so in accordance with the legislation in force.

2. Non-cash payment system with the Cashless Zone is considered good enough to be applied and should be socialized more and more in order to become a banking culture that aims to support the culture of law enforcement to prevent corruption.

\section{REFERENCES}

\section{Books:}

Ermansjah Djaja, Tipologi Tindak Pidana Korupsi di Indonesia, CV. Mandar Maju, Bandung, 2010.

Evi Hartanti, Tindak Pidana Korupsi, Sinar Grafika, Jakarta, 2005.

Surachmin dan Suhandi Cahaya, Strategi dan Teknik Korupsi, Sinar Grafika, Jakarta, 2011.

\section{Newspaper:}

Sumsel Post, Edition September 29, 2015.

\section{Internet:}

http://www.pajak.go.id/content/perbaikansistem-pembayaran-untuk-pencegahankorupsi, accessed on April 27, 2016. 
Hj. Fatria Khairo : The implementation of cashless zone as a strategy to prevent corruption in Indonesia ..... Page 109-116 